\title{
The Influence of Dance Instructional Strategy and Teacher's Pedagogy Competence on Classroom Climate
}

Elindra Yetti, Universitas Negeri Jakarta, Indonesia, elindrayetti@unj.ac.id, ORCID: 0000-0002-3232-5438

Yufiarti, Universitas Negeri Jakarta, Indonesia, yufiarti@unj.ac.id, ORCID: 0000-0002-1444-2833

Erie Siti Syarah, Universitas Negeri Jakarta, Indonesia, ErieSitisyarah_9920919003@mhs.unj.ac.id, ORCID: 0000-0001-7629-7806

Muktia Pramitasari, Universitas Negeri Jakarta, Indonesia, muktia pramitasari@mhs.unj.ac.id, ORCID: 0000-0003-3978-5215

Suharti, Universitas Negeri Jakarta, Indonesia, suharti@mahasiswa.unj.ac.id, ORCID: 0000-0003-07032462

Vina Iasha, Universitas Negeri Jakarta, Indonesia, vina.iasha@gmail.com, ORCID: 0000-0001-7801-6502 Bramianto Setiawan, Universitas PGRI Adi Buana, Indonesia, sbramianto@unipasby.ac.id, ORCID: 00000003-4061-6363

Abstract. The purpose of this study was to determine the effect of various dance strategies and early childhood teachers' pedagogical competence on creating a positive classroom climate which is important for children's academic achievement and social development. This study used a quasi-experimental expost facto design method, with ANOVA to analyse data and test the hypotheses. The respondents in this study involved 176 early childhood teachers. The study found a result of sig. 0.036, indicating that the use of various dance strategies can have a significant positive influence on classroom climate. Other findings indicated that a 'creative' dance strategy that is student-centred, has a greater positive influence on classroom climate than an 'imitative', teacher-centred strategy. Future studies are expected to follow up on other factors that can influence classroom climate as a key to successful learning.

Keywords: Dance instructional strategies, Teachers' pedagogical competencies, Classroom climate

Received: 20.11 .2020

Accepted: 10.12 .2020

Published: 05.01.2021

\section{INTRODUCTION}

Motion development is one of the most important aspects for children raised in a digital world. Kabali et al., (2015) as pediatricians have investigated the Exposure and Use of Mobile Media Devices by Young Children and published their findings at the American Academy of Pediatrics (dedicated to the health of all children), stating that socialization with parental involvement and modeling is very important for the development of healthy and productive ways to integrate digital technology into family life. The Concerns of the children's physical posture when interacting with digital devices and the limited opportunities for motoric development were considered essential in early childhood physical development (Palaiologou, 2016). There are increasing concerns about the effect of digital technology on the emotional well-being of children, particularly with regard to fear, anxiety and depression. This anxiety is resulted by the lack of emotion regulation skills caused by exposure to gadget or digital media that exceeds the limit (Hoge, Bickham, \& Cantor, 2017), and it leads to unpleasant behavior in children at home or classroom. Impaired self-control in the class can cause a negative classroom climate.

Classroom climate and its effect on academic achievement and child development are a widely researched topic (Cadima, Doumen, Verschueren, \& Buyse, 2015; B J Fraser, 1998; Roubinov, Bush, Hagan, Thompson, \& Boyce, 2019; Walker \& Graham, 2019; Westwick, Chromey, \& Westwick, 2015). Positive interactions between teachers and students help create a good classroom climate and contribute to effective learning. It also allows the teacher to assess changes in student behavior and understand the needs of students in the classroom (Che Ahmad, Shaharim, \& Abdullah, 2017). Many studies in education have investigated the importance of a positive classroom climate as an essential prerequisite for children's learning and development (Rachmadtullah et al., 2020). The quality of the preschool classroom climate and its relationship to student engagement over time are determinants of learning achievement. Castro, Granlund, and Almqvist (2017) research during the study period throughout the academic year showed that all variables related to classroom climate increased children's learning achievement. 
The study of classroom climate has produced strategies and practical knowledge to help develop and strengthen the classroom environment. Research findings suggest that fostering a positive classroom climate, and a sense of community for students in an educational environment, is linked to academic retention and success (Westwick et al., 2015). To identify specific actions by teachers who produce a climate in which students feel safe and secure, McCue (2019) found that students need to feel they are important, both in the eyes of the teacher, and with others in the group. Classrooms are the primary social environment affecting children's self-control, although individual differences in physiological reactivity can make children vulnerable to the classroom environment (Roubinov et al., 2019). Classroom climate has been defined as the way in which students experience the psychological and physical characteristics of the classroom (Gillen, Wright, \& Spink, 2011). Classroom climate is directly affected by the interpersonal attitude of the teacher and teacher-student interaction. This is an important element in the teachinglearning process (Telli, Den Brok, \& Cakiroglu, 2007; Van Uden, Ritzen, \& Pieters, 2014). Meeting students' basic learning needs is influenced by the teacher's interpersonal behavior and learning strategies (Korthagen \& Evelein, 2016).

Teacher competencies are needed to provide appropriate instructions for children in creating a positive classroom climate, including in determining learning strategies, especially in dance learning, which is a physical activity by practicing the coordination of movements, thoughts, and feelings. Creative dance learning strategies provide freedom for children to express through motion following their imagination. The result of Sööt and Viskus (2013) research shows that dance learning provides the experience of selfcontrol in children in the classroom. A study by Lillvist et al., (2014) on 810 early-childhood teacher education students, indicated that preschool teacher competencies include six different dimensions: general pedagogical competencies, specific content competencies, competencies of different teachers, play competencies, child perspective competencies, and collaborative and social competencies.

A positive classroom climate requires teachers who are competent in building interactions using appropriate instructional strategies. Teaching requires knowledge, skills and competencies related to contenting, classroom management, and teaching approaches and practices used in their educational settings (McNally \& Slutsky, 2018; Veziroglu-Celik \& Acar, 2018). Positive interactions in the classroom are important, as children draw experiences, mostly through teacher guidance. The most significant impact on children's academic and social success is empowerment by teachers, especially in early childhood (Acar, Hong, \& Wu, 2017).

Teachers require various competencies to work effectively with children. Vital aspects of a teacher's competence are knowledge, pedagogical approaches, and learning attitudes. The relationship between teacher education and classroom quality, the quality of interactions in the classroom, and children's academic achievement, has been examined through cross-sectional and longitudinal studies. The studies have shown that highly competent teachers can substantially improve not only learning and success in school, but also self-worth and children's attitudes towards lifelong learning. The way the teacher carries out their profession affects children individually. Research into early childhood teacher education programs carried out by Lillvist et al., (2014) focused on the competencies needed to develop early childhood education, and how the early childhood teacher education program seeks to prepare teachers with high competencies. Kim and Park (2018) showed a positive relationship between a teacher's pedagogical competence, and child development. Likewise, Maskit and Firstater (2016) research demonstrated that preschool teachers who consider their work as a profession have a good attitude towards pedagogical changes. In addition, teaching styles and learning strategies-children-centered are also significant predictors of teaching success (Dilekli \& Tezci, 2016).

Creative dance can be an effective mechanism for increasing social competence and improving behavior in preschool children. The development of knowledge about dance can help teachers find easy ways in which dance can facilitate learning in other fields of education (Giguere, 2011). The early childhood environment is well positioned to promote physical activity and play a proactive role in the development of a healthy active lifestyle through dance. Routine body movement can positively influence children's health, and their ability to learn (Lu \& Montague, 2016).

The use of dance activities with an emphasis on creative strategies, is one of the main components of early childhood education and is an example of child-centred learning. Instructional strategies used to teach dance can be designed so that children are directly involved and free to create with the guidance of the teacher. This approach has several similarities with the Midway model on dance pedagogy (The Midway model for dance arts in education, combines two poles: the pedagogical (process) model and the model of professional dance teaching. The pedagogical model is based on the process and is the most important element of dance creation), which emphasizes the creative process and dance appreciation. The teacher takes into account the characteristics of the child's development and is open to children's ideas while encouraging the child to explore elements of dance in a fun way. Geršak (2015) attempted to apply the 
concept of dance pedagogy by educating teachers to master dance teaching strategies through a studentcentred approach. This approach emphasizes the creative process whereby the teacher encourages the students to explore elements of dance playfully.

The dance instructional strategies were chosen for this study to determine whether the use of dance can create a positive climate in the early childhood classroom. Dance learning is an activity that can improve intellectual, physical, and sensory responses (Bannon, 2010). So that it can provide new experiences for children to learn self-control in the classroom. Many theorists and practitioners advocate the holistic benefits of education in and through dance (Sööt \& Viskus, 2013).

Previous research by Williams exploring the effectiveness of music interventions in preschool students, delivered over eight weeks, which focused on coordinated rhythmic movements with music to improve self-regulation and executive functions became the basis for this research to develop dance instructional strategy research. The study involved 113 children in three preschools in disadvantaged communities. For eight weeks, the intervention group earned 16 rhythm and movement program sessions, while the control group performed the regular preschool program for the control group. These preliminary findings indicate that rhythm and movement interventions have the potential to support the development of self-regulation skills as a factor to build a positive classroom climate in preschool (Williams \& Berthelsen, 2019).

Based on the facts of the problem in the field about the climate of early childhood classes, the focus of this research is to continue previous studies that have highlighted the importance of a positive classroom climate to improve learning outcomes and solve problems of self-control and involvement of children in the classroom. This study aims to look at the effect of dance learning strategies on early childhood's classroom climate and see the effects of teacher pedagogical competence in the process of applying dance learning instruction.

\section{METHODS}

This study used a quasi-experimental ex-post facto design method. Independent variables in this study are: (1) Dance instructional strategies, (2) Teacher pedagogical competence, while the dependent variable is the climate of early childhood classrooms. The research design is shown in Table 1.

This research was conducted in Indonesia, specifically in DKI Jakarta Province. Participants in this research were 176 early childhood teachers. The sampling technique was conducted by using a purposive sampling because this research was only for schools that conduct early childhood dance learning in class. The Classroom Environmental Scale (CES) instrument was used as a source of predictor variables and criteria in various ways in studies conducted in the United States and Australia. Using the CES dimension as a predictor variable established the relationship between the nature of classroom satisfaction and student mood and environment. The instrument was originally built by Fraser and Fisher (1986). This research modified the instrument to fit the class of early childhood and to become an assessment tool in the classroom climate. Therefore, based on the theory of early childhood characteristics and the theory of teacher competence, researchers modified the CES instrument and the research instrument validation was carried out through instrument validation by early childhood education experts and child psychologists.

Table 1. Research Experiment Design

\begin{tabular}{|l|l|l|l|}
\hline & \multicolumn{3}{|l|}{ Instructional strategies } \\
\hline Teacher Competency & $\begin{array}{l}\text { Creative Dance } \\
\text { Instructional } \\
\text { Strategies }\left(\mathrm{A}_{\mathbf{1}}\right)\end{array}$ & $>$ & $\begin{array}{l}\text { Imitative Dance } \\
\text { Instructional } \\
\text { Strategies }\left(\mathrm{A}_{\mathbf{2}}\right)\end{array}$ \\
\hline $\mathrm{B}_{1}=$ High & $\mathrm{A}_{1} \mathrm{~B}_{1}$ & $>$ & $\mathrm{A}_{2} \mathrm{~B}_{1}$ \\
\hline $\mathbf{B}_{2}=$ Low & $\mathrm{A}_{1} \mathrm{~B}_{2}$ & $>$ & $\mathrm{A}_{2} \mathrm{~B}_{2}$ \\
\hline
\end{tabular}

Information:

$\mathrm{A}_{1} \quad=$ Creative Dance Instructional Strategies

$\mathrm{A}_{2} \quad=$ Imitative Dance Instructional Strategies

$\mathrm{B}_{1} \quad=$ High Teacher Competency

$\mathrm{B}_{2} \quad=$ Low Teacher Competency

$\mathrm{A}_{1} \mathrm{~B}_{1} \quad=$ The group of teachers with Creative Dance Instructional Strategies and

High Teacher Competency

$\mathrm{A}_{1} \mathrm{~B}_{2} \quad=$ The group of teachers with Creative Dance Instructional Strategies and

Low Teacher Competency

$\mathrm{A}_{2} \mathrm{~B}_{1} \quad=$ Group of Teachers with Imitative Dance Instructional Strategies and 
High Teacher Competency

$\mathrm{A}_{2} \mathrm{~B}_{2} \quad=$ Group of Teachers with Imitative Dance Instructional Strategies and

Low Teacher Competency

Data were collected using research instruments related to creative and imitative dance teaching strategies, teacher's pedagogical competencies, and classroom climate. The type of data in this study was the teacher's pedagogical competency variable using ordinal data, while for the class climate variable using interval data. The research instruments were developed by the researchers, passed the expert validation test in their fields, and were modified for this research. The study procedure began with: (1) Conducting preliminary research and identification of the research problems, (2) Reviewing the literature and compiling the research instruments (3) Validating research instruments through instrument validation by early childhood education experts and child psychologists, (4) Retrieving research data of research data in DKI Jakarta Province (5) Analysing the research data (6) Compiling the results and discussion of research.

Data were analyzed using the two-way ANOVA method, which aimed to find out whether there was an influence between dance instructional strategies used in class climate and teacher competency factors that also affect class climate. Teacher competency factors were grouped into two namely high teachers' pedagogic competency and low teacher pedagogic competency group.

\section{RESULTS}

The findings in the study showed that strategic dance learning had a significant a positive effect on class climate, namely the ability of children to self-regulate in the classroom. Table 2 shows the average value of the climate class grade based on Dance Instructional Strategy (DIS) and Teacher Pedagogic Competencies (TPC). Creative Dance Instructional Strategy (CDIS) with High Teacher Pedagogic Competencies (HTPC) is 23,20; CDIS with Low Teacher Pedagogic Competencies (L-TPS) is 22,26; Imitative Dance Instructional Strategy (IDIS) with H-TPC is 21,76, and IDIS with L-TPC is 21,37. Based on these results that CDIS with HTPC has the highest value, this answers that there is a positive influence of DIS and H-TPC on Classroom Climate (CC), both of them being the most complete combination in improving positive class climate.

Table 2. The average value of the classroom climate grade based on DIS and TPC

\begin{tabular}{|c|c|c|c|c|}
\hline \multicolumn{5}{|c|}{ Dependent Variable: CC (Classroom Climate) } \\
\hline \multirow{3}{*}{ DIS } & TPC & Mean & Std. Deviation & N \\
\hline \multirow{3}{*}{ CDIS } & H-TPC & 23.20 & 4.026 & 45 \\
\cline { 2 - 5 } & L-TPC & 22.26 & 3.332 & 43 \\
\cline { 2 - 5 } & Total & 22.74 & 3.712 & 88 \\
\hline \multirow{3}{*}{ Total } & H-TPC & 21.76 & 3.809 & 45 \\
\cline { 2 - 5 } & L-TPC & 21.37 & 3.388 & 43 \\
\cline { 2 - 5 } & Total & 21.57 & 3.594 & 88 \\
\cline { 2 - 5 } & H-TPC & 22.48 & 3.964 & 90 \\
\cline { 2 - 5 } & L-TPC & 21.81 & 3.369 & 86 \\
\hline
\end{tabular}

Test of Between-Subject Effects at the significance value of the intercept (see table 3), the results showed $0,000<0.05$ (Alfa) = Significant. This means that there is a change in the value of the dependent variable without the need to influence the independent variable, and there is a significant model effect on class climate. The effect of DIS on CC in the model shows a significance value of $0.036<0.05$ (Alpha) = Significant. This means that DIS has a positive effect on class climate.

Table 3. Test of between-subject effects

\begin{tabular}{|c|c|c|c|c|c|}
\hline \multicolumn{7}{|c|}{ Dependent Variable: CC } \\
\hline Source & Type III Sum of Squares & Df & Mean Square & F & Sig. \\
\hline Corrected Model & 83.114 a & 3 & 27.705 & 2.072 & .106 \\
\hline Intercept & 86272.743 & 1 & 86272.743 & 6452.420 & .000 \\
\hline DIS & 59.593 & 1 & 59.593 & 4.457 & .036 \\
\hline TPC & 19.379 & 1 & 19.379 & 1.449 & .230 \\
\hline DIS TPC & 3.457 & 1 & 3.457 & .259 & .612 \\
\hline Error & 2299.744 & 172 & 13.371 & & \\
\hline Total & 88759.000 & 176 & & & \\
\hline
\end{tabular}


The effect of TPC on CC in the model shows the results of the significance value of $0.230<0.05$ (Alfa) $=$ not significant, the results explained that strategies in learning became more important than teacher competence. The results showed that TPC had no effect on class climate, in this case. The effect of DIS and TPC together on class climate in the model shows a significance value of $0.612<0.05$ (Alpha) = Not Significant., this shows that good instructional strategies in learning can help teachers with low competencies, this means that teachers with low competence will be able to achieve good children's learning outcomes when he uses creative instructional strategies, because the results also show that teacher competencies do not significantly influence classroom climate.

The plot diagram on figure 1, is useful for assessing whether there are interaction effects between variables. The lines show alignment, so there is no suspected interaction effect. This result means that DIS and TPC together does not have a positive influence on class climate. This result showed that there is no interaction between DIS and TPC.

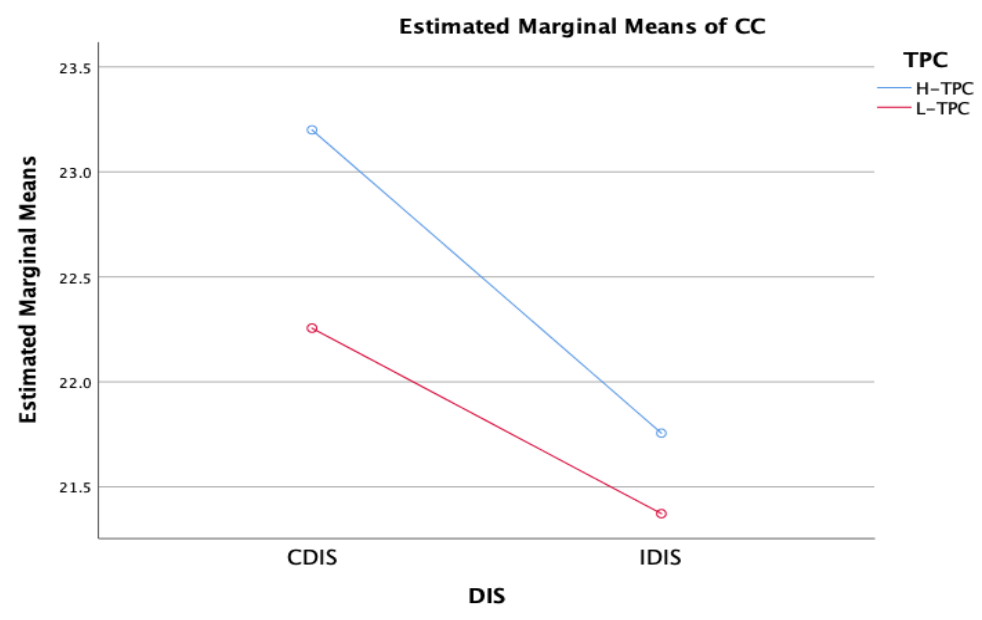

Figure 1. Interaction between DIS and TPC

Table 4 shows the average value of class climate data based on DIS and TPC descriptive. The results of the largest average value are the average of CDIS with H-TPC to CC around 23,200, and the smallest is the value on the IDIS model with L-TPC this shows that CDIS is superior to IDIS in creating a positive class climate. As well as H-TPC is superior to L-TPC. Together, CDIS and H-TPC needs attention used as one of the instructional learning programs in early childhood classes.

Table 4. The average value of classroom climate data based on DIS and TPC descriptive (DIS*TPC)

\begin{tabular}{|c|c|c|c|c|c|}
\hline \multicolumn{5}{|c|}{ Dependent Variable: CC } \\
\hline \multirow{2}{*}{ DIS } & \multirow{2}{*}{ TPC } & \multirow{2}{*}{ Mean } & \multirow{2}{*}{ Std. Error } & \multicolumn{2}{c|}{ 95\% Confidence Interval } \\
\cline { 4 - 6 } & & & Lower Bound & Upper Bound \\
\hline \multirow{2}{*}{ CDIS } & H-TPC & 23.200 & .545 & 22.124 & 24.276 \\
\cline { 2 - 6 } & L-TPC & 22.256 & .558 & 21.155 & 23.356 \\
\hline \multirow{2}{*}{ TPC } & H-TPC & 21.756 & .545 & 20.680 & 22.831 \\
\cline { 2 - 6 } & L-TPC & 21.372 & .558 & 20.271 & 22.473 \\
\hline
\end{tabular}

\section{DISCUSSION and CONCLUSIONS}

Teachers with high pedagogical competence can create a classroom climate that supports children's development such as learning strategies that encourage children's social and emotional development, including the ability to adjust their behavior (J. Downer, Sabol, \& Hamre, 2010). Creative dance strategies can open communication in the classroom and provide positive emotions to be expressed, which can affect the self-control of children in the classroom and make the classroom more supportive of other aspects of development. 


\section{Implementing Dance Instructional Strategies}

The creative dance learning strategies produce behavioral changes in early childhood. Changes were seen in the form of calm interactions in the classroom, or when completing assignments in class based on data in the table 1 show the result of the highest value of mean that Creative Dance Instructional Strategy (CDIS) with High Teacher Pedagogic Competencies (HTPC) is 23,20. Classroom learning strategies that support positive feelings encourage children's social and emotional development, including the adjustment of their behavior (J. T. Downer et al., 2011). Creative dance learning strategies have opened communication in the classroom and provided good emotions that can affect children's self-control in the classroom and make the classroom climate more supportive.

Student-centered dance instructional strategies in early childhood have improved aspects of social development, especially in relation to self-regulation, which are indicators of a positive classroom climate. Efforts towards self-control are related to high quality of social skills, relationships with teachers and peers, school involvement, and academic performance (Duckworth, Gendler, \& Gross, 2014). Children's participation in dance has the potential positively to influence many aspects of a child's development, including physical, cognitive, psychological, and social functions. Dancing is an activity that requires a combination of body movement and thinking processes and can improve physical outcomes such as cardiovascular fitness and bone health, and cognitive outcomes such as attention and concentration (May et al., 2019). By enhancing aspects of healthy child development, dancing provides opportunities for young children to be active and explore the capacity of body movements (Allender, Cowburn, \& Foster, 2006).

\section{High Teacher Pedagogic Competencies for Classroom Climate}

Emotional support was found to the best predictor of student involvement in the class (Aydoğan, Farran, \& Sağsöz, 2015). Although there is no direct relationship between the level of emotion observed in the classroom in the state of the class climate, there is a shared influence between the teacher's instruction and the child's emotional level in a positive classroom climate and this justifies the teacher's precise and effective instruction to increase children's involvement in class. The application of learning strategy is part of the teacher's pedagogical competence, a child-centered learning strategy that can affect the classroom climate. This can be said that the teacher shows awareness about the potential for improvisation in dance education, as well as the skills and competencies developed during educational activities (Biasutti, 2013). The findings revealed that a student-centered approach was more effective than a teacher-centered approach, because almost all teachers with high pedagogical competence apply student-centered learning (Yamagata, 2018). Creative teacher education practices can help teachers develop a positive classroom climate. Therefore, teacher education programs should include components that foster teacher creativity and enthusiasm (Cheung, Fong, Leung, \& Ling, 2019).

A teacher should provide emotional support in the classroom by creating experiences that foster a higher level of involvement in the children in the learning process (Aydoğan et al., 2015). A high-quality classroom climate occurs when a teacher uses proactive behavior management strategies to prevent undesirable behavior; monitors the class carefully to keep children engaged in academic assignments; and builds predictable and consistent routines so that children understand behavior expectations (Hoge et al., 2017). Jeon, Buettner, and Grant (2018) research results say that to help teachers build competence and master learning strategies to overcome the pressure of the work environment and reduce their psychological burden. The research also suggests that a positive classroom climate should be created for early childhood education teachers.

One indicator used in assessing classroom climate is whether the behavior of a child is accepted by teachers and peers. It is a challenge for teachers, to adapt the learning environment to be more inclusive for children who may not have been accepted into the classroom environment. When starting kindergarten, children become part of a peer environment. Some children will be liked or accepted, while others may be disliked. When children are accepted by their peers, they have sufficient opportunities to engage in various social interactions. Children who are not accepted, lose vital social cues, which can lead to increased behavior problems such as externalizing behavior. Children who are accepted by others, may feel an increased sense of self-worth. Children who are not accepted by peers, however, lose this validation and risk developing negative self-concepts (Rubin, Bukowski, \& Bowker, 2015).

Results of this study indicate that high teacher competence lacks a significant effect on the quality of the classroom climate, this shows that even teachers with high competencies will find it difficult to achieve good children's learning outcomes when they do not use creative instructional strategies. This can be related to the background of teacher education. Research on developing the competency of ECE teacher candidates during education identified that teachers were expected to receive adequate training and education (Strohmer \& Mischo, 2016), to improve competence, and cases in TK teacher education in Indonesia were uneven competencies due to lack of training facilities for teachers. 


\section{The Strongest Influences Factors for Positive Classroom Climate}

The main finding of this study was that the classroom climate is significantly influenced by both creative dance learning strategies, and high teacher pedagogical competence. The teacher shows awareness about the potential for improvisation in dance education, as well as the skills and competencies developed during learning activities (Biasutti, 2013). A student-centered approach to teaching dance improvisation, and the relationship between the motor, cognitive and emotive domains, has been proven to be significant. Preschool dance learning activities designed to stimulate motor synchronization and coordination skills and embedded in group activities can improve children's motor function, hearing, and self-control (Williams \& Berthelsen, 2019). This is consistent with our research findings that dance learning strategies can influence children's self-control and result in a positive classroom climate for peers.

According to Geršak (2015) who attempted to apply the concept of dance pedagogy by educating teachers to master dance teaching strategies through a student-centred approach stressing that the creative process is when the teacher can encourage students to explore dance elements by playing around. Another important factor influencing the classroom climate is that children could organize themselves through play activities with their peers, and through other activities that involve discussion, negotiation, and making suggestions while interacting with others. When teachers create opportunities for children to participate in decision making, they support children's self-regulation by allowing independent initiatives to be voiced and acted upon (Kangas, Ojala, \& Venninen, 2015).

The conclusion of this study indicates that dance learning strategies and teacher pedagogical competencies in a preschool environment, both have a significant influence on classroom climate. Furthermore, there is a higher positive influence when using creative dance learning strategies, rather than imitative dance learning strategies. The results also showed that the teacher's competence did not really determine the classroom climate, but creative dance instruction strategies could give a positive value to the classroom climate. This advantage is in the dance activities with creative strategies in children cause a sense of joy that brings to the child's emotional development which is one of the keys to a positive classroom climate. Early childhood educators need to realize that dance learning activities can be used as a moment to warm up before conducting other learning activities. The Results of this study can be used as a reference with well-organized emotions because of dancing in a way pleases children, will bring good results in the achievement of other children's development. The implications of further research are expected to be to follow up on other factors that can affect the classroom climate as a key to successful learning.

\section{REFERENCES}

Acar, I. H., Hong, S. Y., \& Wu, C. R. (2017). Examining the role of teacher presence and scaffolding in preschoolers' peer interactions. European Early Childhood Education Research Journal, 25(6), 866884. https://doi.org/10.1080/1350293X.2017.1380884

Allender, S., Cowburn, G., \& Foster, C. (2006). Understanding participation in sport and physical activity among children and adults: A review of qualitative studies. Health Education Research, 21(6), 826835. https://doi.org/10.1093/her/cyl063

Aydoğan, C., Farran, D. C., \& Sağsöz, G. (2015). The relationship between kindergarten classroom environment and children's engagement. European Early Childhood Education Research Journal, 23(5), 604-618. https://doi.org/10.1080/1350293X.2015.1104036

Bannon, F. (2010). Dance: The possibilities of a discipline. Research in Dance Education, 11(1), 49-59. https://doi.org/10.1080/14647890903568313

Biasutti, M. (2013). Improvisation in dance education: teacher views. Research in Dance Education, 14(2), 120-140. https://doi.org/10.1080/14647893.2012.761193

Cadima, J., Doumen, S., Verschueren, K., \& Buyse, E. (2015). Child engagement in the transition to school: Contributions of self-regulation, teacher-child relationships and classroom climate. Early Childhood Research Quarterly, 32, 1-12. https://doi.org/10.1016/j.ecresq.2015.01.008

Castro, S., Granlund, M., \& Almqvist, L. (2017). The relationship between classroom quality-related variables and engagement levels in Swedish preschool classrooms: a longitudinal study. European Early Childhood Education Research Journal, 25(1), 122-135. https://doi.org/10.1080/1350293X.2015.1102413

Che Ahmad, C. N., Shaharim, S. A., \& Abdullah, M. F. N. L. (2017). Teacher-student interactions, learning commitment, learning environment and their relationship with student learning comfort. Journal of Turkish Science Education, 14(1), 57-72. https://doi.org/10.12973/tused.10190a

Cheung, S. K., Fong, R. W. tsz, Leung, S. K. Y., \& Ling, E. K. wei. (2019). The Roles of Hong Kong Preservice 
Early Childhood Teachers' Creativity and Zest in Their Self-efficacy in Creating Child-centered Learning Environments. Early Education and Development, 00(00), 1-12. https://doi.org/10.1080/10409289.2019.1586224

Dilekli, Y., \& Tezci, E. (2016). The relationship among teachers' classroom practices for teaching thinking skills, teachers' self-efficacy towards teaching thinking skills and teachers' teaching styles. Thinking Skills and Creativity, 21, 144-151. https://doi.org/10.1016/j.tsc.2016.06.001

Downer, J., Sabol, T. J., \& Hamre, B. (2010). Teacher-child interactions in the classroom: Toward a theory of withinand cross-domain links to children's developmental outcomes. Early Education and Development, 21(5), 6999-723. https://doi.org/10.1080/10409289.2010.497453

Downer, J. T., Pianta, R. C., Fan, X., Hamre, B. K., Mashburn, A., \& Justice, L. (2011). Effects of Web-Mediated Teacher Professional Development on the Language and Literacy Skills of Children Enrolled in $\begin{array}{llll}\text { Prekindergarten } \quad \text { Programs. NHSA } & \text { 189-212. }\end{array}$ https://doi.org/10.1080/15240754.2011.613129

Duckworth, A. L., Gendler, T. S., \& Gross, J. J. (2014). Self-Control in School-Age Children. Educational Psychologist, 49(3), 199-217. https://doi.org/10.1080/00461520.2014.926225

Fraser, B J. (1998). Classroom environment instruments: Development, validity and applications. Learning Environments Research, 7-33.

Fraser, Barry J., \& Fisher, D. L. (1986). Using short forms of classroom climate instruments to assess and improve classroom psychosocial environment. Journal of Research in Science Teaching, 23(5), 387413. https://doi.org/10.1002/tea.3660230503

Geršak, V. (2015). Dance in the Slovenian kindergarten curriculum. Journal for Pedagogical Theory and Practice, 64(3), 399-410.

Giguere, M. (2011). Dancing thoughts: An examination of children's cognition and creative process in dance. Research in Dance Education, 12(1), 5-28. https://doi.org/10.1080/14647893.2011.554975

Gillen, A., Wright, A., \& Spink, L. (2011). Student perceptions of a positive climate for learning: A case study. Educational Psychology in Practice, 27(1), 65-82. https://doi.org/10.1080/02667363.2011.549355

Hoge, E., Bickham, D., \& Cantor, J. (2017). Digital media, anxiety, and depression in children. Pediatrics, 140, S76-S80. https://doi.org/10.1542/peds.2016-1758G

Jeon, L., Buettner, C. K., \& Grant, A. A. (2018). Early Childhood Teachers' Psychological Well-Being: Exploring Potential Predictors of Depression, Stress, and Emotional Exhaustion. Early Education and Development, 29(1), 53-69. https://doi.org/10.1080/10409289.2017.1341806

Kabali, H. K., Irigoyen, M. M., Nunez-Davis, R., Budacki, J. G., Mohanty, S. H., Leister, K. P., \& Bonner, R. L. (2015). Exposure and use of mobile media devices by young children. Pediatrics, 136(6), 1044-1050. https://doi.org/10.1542/peds.2015-2151

Kangas, J., Ojala, M., \& Venninen, T. (2015). Children's Self-Regulation in the Context of Participatory Pedagogy in Early Childhood Education. Early Education and Development, 26(5-6), 847-870. https://doi.org/10.1080/10409289.2015.1039434

Kim, S. L., \& Park, C. H. (2018). The Effects of Preschool Teachers ' Qualification and Competency on Young Children' s Development, 6(4), 3-4.

Korthagen, F. A. J., \& Evelein, F. G. (2016). Relations between student teachers' basic needs fulfillment and their teaching behavior. Teaching and Teacher Education, 60, 234-244. https://doi.org/10.1016/j.tate.2016.08.021

Lillvist, A., Sandberg, A., Sheridan, S., \& Williams, P. (2014). Preschool teacher competence viewed from the perspective of students in early childhood teacher education. Journal of Education for Teaching, 40(1), 3-19. https://doi.org/10.1080/02607476.2013.864014

Lu, C., \& Montague, B. (2016). Move to Learn, Learn to Move: Prioritizing Physical Activity in Early Childhood Education Programming. Early Childhood Education Journal, 44(5), 409-417. https://doi.org/10.1007/s10643-015-0730-5

Maskit, D., \& Firstater, E. (2016). Preschool Teachers Perspectives on Teaching as a Profession and Pedagogical Change. Journal of Research in Childhood Education, 30(2), 200-210. https://doi.org/10.1080/02568543.2016.1143417

May, T., Chan, E. S., Lindor, E., McGinley, J., Skouteris, H., Austin, D., ... Rinehart, N. J. (2019). Physical, cognitive, psychological and social effects of dance in children with disabilities: systematic review and $\begin{array}{llll}\text { meta-analysis. Disability } \quad \text { Rehabilitation, } & 0(0),\end{array}$ https://doi.org/10.1080/09638288.2019.1615139

McCue, P. J. (2019). Making A Connection: A Case Study On The Qualities That Promote A Positive Classroom Climate In The Early Childhood Classroom. Miami University.

McNally, S., \& Slutsky, R. (2018). Teacher-child relationships make all the difference: constructing quality interactions in early childhood settings. Early Child Development and Care, 188(5), 508-523. 
https://doi.org/10.1080/03004430.2017.1417854

Palaiologou, I. (2016). Children under five and digital technologies: implications for early years pedagogy. European Early Childhood Education Research Journal, 24(1), 5-24. https://doi.org/10.1080/1350293X.2014.929876

Rachmadtullah, R., Yustitia, V., Setiawan, B., Mahya Fanny, A., Pramulia, P., Susiloningsih, W., Tur Rosidah, C., Prastyo, D., \& Ardhian, T. (2020). The Challenge Of Elementary School Teachers To Encounter Superior Generation In The 4.0 Industrial Revolution: Study Literature. International Journal of Scientific \& Technology Research, 9(4), 1879-1882. www.ijstr.org

Roubinov, D. S., Bush, N. R., Hagan, M. J., Thompson, J., \& Boyce, W. T. (2019). Associations between classroom climate and children's externalizing symptoms: The moderating effect of kindergarten children's parasympathetic reactivity. Development and Psychopathology, 1-12. https://doi.org/10.1017/S095457941900052X

Rubin, K. H., Bukowski, W. M., \& Bowker, J. C. (2015). Children in peer groups. Handbook of child psychology and developmental science (4th Hoboken. https://doi.org/http://dx.doi.org/10.1002/9781118963418. childpsy405

Sööt, A., \& Viskus, E. (2013). Contemporary Approaches to Dance Pedagogy - the Challenges of the 21st Century. The European Journal of Social \& Behavioural Sciences, 7(4), 1193-1202. https://doi.org/10.15405/ejsbs.99

Strohmer, J., \& Mischo, C. (2016). Does early childhood teacher education foster professional competencies? Professional competencies of beginners and graduates in different education tracks in Germany. Early Child Development and Care, 186(1), 42-60. https://doi.org/10.1080/03004430.2014.985217

Telli, S., Den Brok, P., \& Cakiroglu, J. (2007). Students' perceptions of science teachers' interpersonal behaviour in secondary schools: Development of a Turkish version of the Questionnaire on Teacher Interaction. Learning Environments Research, 10(2), 115-129. https://doi.org/10.1007/s10984-0079023-2

Van Uden, J. M., Ritzen, H., \& Pieters, J. M. (2014). Engaging students: The role of teacher beliefs and interpersonal teacher behavior in fostering student engagement in vocational education. Teaching and Teacher Education, 37, 21-32. https://doi.org/10.1016/j.tate.2013.08.005

Veziroglu-Celik, M., \& Acar, I. H. (2018). Teaching Approaches and Practices of Student Teachers in Early Childhood Education: A Convergent Mixed Methods Study. Journal of Education and Training Studies, 6(11), 234. https://doi.org/10.11114/jets.v6i11.3634

Walker, S., \& Graham, L. (2019). At risk students and teacher-student relationships: student characteristics, attitudes to school and classroom climate. International Journal of Inclusive Education, 0(0), 1-18. https://doi.org/10.1080/13603116.2019.1588925

Westwick, J., Chromey, K. J., \& Westwick, J. (2015). A Life-Changing GIFT : The Impact of Classroom Climate and Community Building. Open PRAIRIE: Open Public Research Access Institutional Repository and Information Exchange, 2(Fall), 10-14. Retrieved from http://openprairie.sdstate.edu/commtheatre_pubs

Williams, K. E., \& Berthelsen, D. (2019). Implementation of a rhythm and movement intervention to support self-regulation skills of preschool-aged children in disadvantaged communities. Psychology of Music, 47(6), 800-820. https://doi.org/10.1177/0305735619861433

Yamagata, S. (2018). Comparing core-image-based basic verb learning in an EFL junior high school: Learner-centered and teacher-centered approaches. Language Teaching Research, 22(1), 65-93. https://doi.org/10.1177/1362168816659784 